\title{
Use of fodder resources by ruminants in warm climate countries
}

\author{
C Devendra \\ International Livestock Research Institute (ILRI), PO Box 30709, Nairobi, Kenya \\ Contact address: 8 Jalan 9/5, 46000 Petaling Jaya, Selangor, Malaysia
}

\begin{abstract}
Summary - Fodder resources provide the principal sources of feeds throughout the humid and sub-humid, arid and semi-arid and Mediterranean regions. They include grasses and legumes, and fibrous crop residues (FCR). Browse is another important source of fodder. The availability and use of the fodder resources is dependent on type of agroecosystem (e.g. humid and sub-humid to arid and semi-arid), cropping patterns and their intensity, type and concentration of animal species, and prevailing animal production systems. The productivity of ruminants is dependent on the potential of a feed to supply, through microbial degradation, balanced nutrients for production; digestible dry matter intake is highly correlated with animal productivity with individual feeds. Nutritive value relates to the capacity of a feed to supply nutrients to meet productive functions, and this is contingent on maximizing voluntary feed intake, potential digestibility, protein:energy $(P / E)$ ratio, and availability of bypass nutrients, particularly proteins. FCR form the main base in feeding systems for ruminants throughout the tropics and the Mediterranean region, and in recent years considerable progress has been achieved in their use. A number of technologies can be applied singly or in combination: treatment with alkalis to increase digestibility, supplementation to improve overall digestion and provide balanced nutrients, use of bypass nutrients, and large scale on-farm application to demonstrate economic profitability. Supplementation is central to effective utilization and includes the use of multi-nutrient block licks (MNBL), non-protein nitrogenous sources, and a variety of leguminous forages like Acacia spp., Gliricidia maculata, Leucaena leucocephala and Prosopis juliflora. Given the advances that have been made on the use of FCR, extending known technologies through on-farm testing and demonstration far outweighs the need for further research on the effects of pre-treatments or supplementation. Such effort must involve strategies for more effective use of the fodder resources, especially in large scale participatory onfarm situations. These need to address efficiency in integrated natural resource use, the totality of production-post-production-consumption systems, and demonstration of more sustainable animal production systems.
\end{abstract}

\section{Introduction}

Fodder resources in warm climates provide the principal sources of feeds for ruminants. These refer mainly to three types of feeds: grasses, legumes and fibrous crop residues (FCR). The availability of these, and extent of their utilization is dependent on a variety of factors, but the more important of these are type of agroecosystem (e.g. humid and sub-humid vs arid and semi-arid), cropping patterns and intensity, type and concentration of animal species, and prevailing animal production systems.

At the recent global consultation to define the priority for livestock research, feeding and nutrition is the major constraint to productivity from animals (ILRI, 1995). This emphasises enormous challenges and involves two major issues: firstly, the role of nutrition in maximising food production from livestock given the need for more output, and secondly, contribution to the development of sustainable animal production systems. In practice this simply means taking maximum advantage of available dietary ingredients and identify this clearly in terms of performance, productivity and profitability.

The type of agroecosystem exerts considerable influence on the animal production systems. In Asia for example, mixed irrigated systems in the humid, sub-humid and sub-tropics enable two to three crops of rice per year, which together with high yielding varieties of rice produce considerable quantities of rice straw. Relay cropping with short term crops with maize for example, further increase the volume of crop residues 
produced. In the Mediterranean region, traditional silvopastoral systems are common and are widely grown together with medic (Medicago spp.) pasture-cereal system in rotation with dry land crops such as lupin, field pea, lentil, chick pea, faba bean and vetch. These produce considerable crop residues like cereal straws, legume straws and hay (e.g. lentil and vetch) and provide the main sources of roughages. By comparison in the rainfed arid and semi-arid ecosystem, rangelands which are in a worsening situation, provide the main feed resources of about $30 \%$ of the feed requirements of animals, with additional supplies from cereal straws and crop stubbles. In such feed deficit situations, concentrate feeding is normal (see for example Vecht et al, 1991, with dairy goats) often involving the use of cereal grains and are justified on economic grounds.

Countries in the humid and sub-humid environments such as in Latin America, West Africa and South East Asia, by comparison, generally have more abundant fodder resources than those in the Mediterranean and arid and semi-arid regions such as in northern Africa, and many countries in West Asia. However, the problem is far more acute in the arid and semi-arid ecosystem where inadequate feed production induces chronic feed deficits and a major limitation to productivity from animals. Additionally, the presence of relatively large concentrations of animals and very extensive systems further exacerbate the situation.

This paper is concerned with the use of fodder resources (grasses, legumes and fibrous crop residues) by ruminants in warm climates. It presents a brief background to intake and nutritive value of strategies to increase their utilization through the application of known technology and the development of environmentally sustainable production systems.

\section{Voluntary feed intake}

Central to ensuring effective and maximum use of the fodder resources is voluntary intake. Voluntary Feed Intake (VFI) is the single most important factor affecting production in animals and is also associated with digestibility of the feed, and proportion of the digested material that's absorbed. This is reflected in the equation: $\mathrm{VFI}=\mathrm{D} \times \mathrm{E}$ where

$\mathrm{VFI}=$ Voluntary Feed Intake

$\mathrm{D}=$ Digestibility of the feed eaten,

$\mathrm{E}=$ Efficiency of extraction of nutrients in that feed during digestion.

Maximizing VFI and ensuring the supply of balanced nutrients (energy, proteins and minerals) in the diet thus greatly determine productivity, be it meat, milk or fibre. It represents the first prerequisite in feeding systems which can make available fodder and supplementary nutrients that are appropriate to different types of production. The productivity of ruminants is thus linked to the potential of a feed to supply through effective microbial degradation, quantities and balance of nutrients for production. Digestible dry matter intake $(D \times E)$ is highly correlated with animal productivity with anyone feed.

\section{Chemical composition and nutritive value}

The relatively low digestibility of tropical grasses is associated with high proportions of highly lignified tissues scattered through the leaf stem and sheat. Some idea of the extent of cell wall composition in selected tropical grasses, forages, and tree legumes from Indonesia has been reported by Lowry et al (1992) in table I. The table shows that tropical legumes have relatively lower cell wall content and consequently higher nutritive value. Not with standing the relatively higher lignin content, tropical legumes have a consistently higher nutritive value.

The VFI and therefore availability of nutrients in forages depends on their resistance to breakdown (Balch and Campling, 1962; Troelsen and Campbell, 1969; Chenost, 1966). Minson (1990a) has reported that the mean intake of 450 fresh or dried tropical grasses by sheep was $50.8 \mathrm{~g} / \mathrm{kg}^{0.75} /$ day compared to $67.3 \mathrm{~g} / \mathrm{kg}^{0.75} /$ day for temperate grasses. For 16 tropical legumes the mean VFI

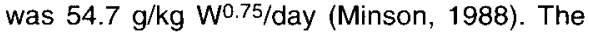
mean rate of fall in VFI for a number of tropical grasses was $0.17 \mathrm{~g} / \mathrm{kg} \mathrm{W0.75/day} \mathrm{(Minson,}$ 1990b). Bacteria can digest the lignified tissue of grasses (Chesson et al, 1986), whereas the vascular tissues of legumes are completely indigestible (Wilson et al, 1991). The digestibility of tropical legumes is thus more completely related to the proportion of vascular 
Table I. The composition of the cell walls of tropical grasses and tropical forage and tree legumes (adapted from Lowry et al, 1992).

\begin{tabular}{lc}
$\begin{array}{l}\text { Forage component } \\
(\mathrm{g} / \mathrm{kg} \text { dry matter) }\end{array}$ & $\begin{array}{c}\text { Tropical forage } \\
\text { legumes }\end{array}$ \\
\hline Cell walls (NDF) & 430 \\
Hemicellulose & 130 \\
Lignin & 73 \\
Lignin/cellulose & $0.32 \pm 0.12$ \\
Lignin/cell wall & $0.17 \pm 0.06$ \\
Number of species & 17
\end{tabular}

tissue than to its lignin content. On the other hand, legumes have higher concentrations of cellular proteins.

The nutritive value in forages relates to their capacity to supply nutrients in proportions balanced to meet particular productive functions (Leng, 1986). This capacity is contingent on the following interrelated aspects: voluntary feed intake; potential digestibility; protein:energy $(P / E)$ ratio; fermentation glucogenic (propionic acid) energy/total VFA $(G / E)$; bypass nutrient potential (proteins, lipids and starch).

It is also appropriate to keep in prospective that in especially warm climates, nutritive value of forages is affected by several factors. These include temperature, proportion of leaves and stems, fertilizers, stage of growth, protein and mineral contents. In grass for example, with increasing maturity, the proportion of leaves decreases and that of stem increases, resulting in decreased nutritive value. In legumes, these changes are less marked, and the nutritive value therefore declines at a slower rate than grasses. Factors affecting the nutritive value of forages have been discussed in detail (Minson, 1990b).

Associated with nutritive value the protein:energy $(\mathrm{P} / \mathrm{E})$ ratio which is an important factor concerned with the efficiency of feed utilization. Since anaerobic fermentative digestion in the rumen provides microbial cells which supply the protein to the animal, the efficiency of microbial growth therefore influences the P/E ratio. Poor microbial growth due to inadequate dietary $\mathrm{N}$ for example, will result in a low $P / E$ ratio and, conversely, adequate supplementation and good rumen function enables a good $P / E$ in the nutrients

$\begin{array}{cc}\begin{array}{c}\text { Tropical tree } \\ \text { legumes }\end{array} & \begin{array}{c}\text { Tropical } \\ \text { grasses }\end{array} \\ 370 & 660 \\ 100 & 280 \\ 114 & 47 \\ 0.73 \pm 0.30 & 0.14 \pm 0.04 \\ 0.31 \pm 0.09 & 0.07 \pm 0.02 \\ 18 & 41\end{array}$

available to the animal (Leng, 1982). Intake has been shown to be more sensitive to P/E ratios rather than to volatile fatty acid (VFA) proportions, and legumes have the greatest potential to alter the former due to higher $\mathrm{CP}$ contents and often lower degradation rates caused by tannins (Poppi et al, 1990). However, tropical legumes appear to be less effective in altering VFA patterns and P/E ratios than temperate legumes (Poppi and McLennan, 1995). P/E ratios are therefore very valuable in reflecting the extent of an unbalanced diet and level of supplementation with a combination of non-protein nitrogen (NPN) and minerals that are necessary.

\section{Browse}

One other fodder resource which is important for use by ruminants, but underestimated, is browse. Browse refers to the tender shoots, twigs and leaves of shrubs and woody plants, fruits and pods. They provide most valuable nutrients for a variety of herbivores throughout the tropics, but especially in arid and semi-arid and the Mediterranean regions (Devendra, 1995). The importance of browse in the diet of herbivores is reflected in reports from Africa, Latin America and Australia. In northern Africa, browse forms $60-70 \%$ of rangeland production and $40 \%$ of the total availability of animal feeds in the region. The annual production is about $1.5 \mathrm{~kg}$ of dry matter (DM) ha-1. $\mathrm{mm}^{-1}$ of annual rainfall of which $50 \%$ is consumed (Le Houerou, 1980). Browse is also a component of alley copping (Sumberg, 1984). In India, browse is the principal feed for goats and meets over $60-70 \%$ of the forage 
requirements, of which the leguminous types are especially important.

The nutritional relevance of browse is especially important for free ranging herbivores in extensive and very extensive systems in which goats, sheep and camels utilize the feed more than cattle and buffaloes. Between goats and sheep, the former depend to a very large extent on browse to meet their feed requirements throughout Asia, Africa, the Near East and Latin America (Devendra and Burns, 1983). The real value of browse is that it increases with decreasing quality of grazing and feed availability.

In extreme arid environments, browse enables survival of cattle, sheep and goats, and is reflected in the data of Sarson and Salmon (1978). An analysis of the maintenance needs of these animals showed that browse (the nutritional value of which varies from 2.95 to 5.31 MJME. $\mathrm{kg}^{-1} \mathrm{DM}$ ) alone cannot ensure the maintenance requirements of cattle (6.02 MJME. $\left.\mathrm{kg}^{-1} \mathrm{DM}\right)$. It can, however, ensure the maintenance of sheep (5.17 MJME. $\mathrm{kg}^{-1} \mathrm{DM}$ ), but does not allow production, while for goats, maintenance and production may be provided on a pure browse diet $(4.72$ MJME. $\mathrm{kg}^{-1} \mathrm{DM}$ ). The data explain why only goats, camels and some wild herbivores can survive on depleted rangelands, where browse constitutes most of the feed. It also explains why goats and camels are less affected by catastrophic droughts in the Sahel of Africa, compared with sheep and cattle (Le Houerou, 1978).

\section{Fibrous crop residues}

Fibrous crop residues (FCR) form the main base in feeding systems throughout countries with warm climates. These refer mainly to cereal straws as well as a variety of other feeds such as sugarcane tops, bagasse, cocoa pod husks, pineapple waste and coffee seed pulp, all of which are generally produced with high biomass in humid and sub-humid regions. In the Mediterranean region, crop residues (straw, stubble and fallow) are also abundant and also include cereal grain by-products, olive by-products, by-products from fruit and vegetable canning, and also industrial crops such as sunflower seed and sugarbeet.

Enhancing their utilization, particularly in efficient feeding systems that can cost- effectively convert these into meat or milk is the most important challenge. To this end, considerable progress has been made throughout the developing countries and elsewhere to meet this objective. Progress in this direction relates to a number of well researched technologies which can be applied singly or in combination as follows:

-treatment with alkalis to increase digestibility and Voluntary Feed Intake;

-supplementation to improve overall digestion and to provide nutrients;

-rumen manipulation to improve and provide balanced nutrients from the rumen;

-use of bypass nutrients in supplements (proteins, fats and starch) to effectively meet the nutrient requirements for production, and -application and demonstration of appropriate technology to farmers at the farm level, such that responses in animals are associated with cost-effective feasibility, profitability and replicability;

Chemical treatment with alkalis has been practised for a long time with variable success. Where cereal crops are irrigated, the volume of cereal straws produced is greater than in rainfed areas due to double or triple cropping. The opportunities for straw treatment to increase digestibility are therefore more attractive and have been widely undertaken. In the Mediterranean region, the efforts with barley straw have been generally more successful than the treatment and use of rice straw in Asia. The problem in the latter situation, is related more to extension of the developed technology leading to variable rates of adoption; specific steps to improve this situation have recently been suggested (Leng and Devendra, 1995). The availability and use of more easily digestible treated straw provides an excellent basis to stimulate maximum response in animals with appropriate supplementation.

\section{Supplementation}

Supplementation is an important intervention to increase the utilization of FCR, in view of their low digestibility and nutritive value. The availability of supplements is therefore a most important prerequisite in enhancing the utilization of FCR irrespective of whether these are treated or untreated with alkalis to improve digestibility and VFI. These supplements serve 
Table II. Average feed intake over a six month trial with Mehsani buffaloes (and cross breds cattle in Boriavi's and Fatehpura's villages) fed according to village management and supplemented with a molasses urea multi nutrient block (UMNB)" (Manget-Ram et al, personal communication).

\begin{tabular}{|c|c|c|c|c|c|c|c|c|c|c|}
\hline \multirow{2}{*}{$\begin{array}{l}\text { Village } \\
\text { UMNB Supp }\end{array}$} & \multirow{2}{*}{$\begin{array}{l}\text { Animals } \\
\text { lementation }\end{array}$} & \multicolumn{2}{|c|}{$\begin{array}{c}\text { Green fodder }{ }^{1} \\
\text { intake }(\mathrm{kg} / \mathrm{d})\end{array}$} & \multicolumn{2}{|c|}{$\begin{array}{l}\text { Dry fodder }{ }^{2} \\
\text { intake }(\mathrm{kg} / \mathrm{d})\end{array}$} & \multicolumn{2}{|c|}{$\begin{array}{l}\text { Concentrate } \\
\text { intake }(\mathrm{kg} / \mathrm{d})\end{array}$} & \multicolumn{2}{|c|}{$\begin{array}{c}\text { DM intake } \\
(\mathrm{kg} / \mathrm{d})\end{array}$} & \multirow[t]{2}{*}{$\begin{array}{l}\text { UMNB intake } \\
\text { Av. }(g / d)\end{array}$} \\
\hline & & - & + & - & + & - & + & - & + & \\
\hline Boriavi 5 & 36 & 25.5 & 25.9 & 6.4 & 6.7 & 7.3 & 7.2 & 22.5 & 22.9 & 204 \\
\hline Ejipura & 28 & 21.5 & 22.6 & 8.6 & 8.7 & 3.6 & 3.6 & 10.6 & 20.2 & 204 \\
\hline Bhesana & 34 & 13.2 & 13.2 & 7.0 & 7.6 & 3.4 & 3.3 & 14.6 & 15.1 & 210 \\
\hline Dholasan & 48 & 16.7 & 16.8 & 7.1 & 7.3 & 7.2 & 7.2 & 19.6 & 19.8 & 136 \\
\hline Fatehpura 6 & 28 & 22.4 & 25.1 & 7.7 & 9.1 & 6.2 & 6.9 & 21.5 & 24.4 & 330 \\
\hline
\end{tabular}

${ }^{1}$ Green fodder - usually sorghum, road side grass or napier grass fed at a constant rate; ${ }^{2}$ Crop residue - mainly millet straw fed ad libitum; ${ }^{3}$ Local concentrate composed of agro-industrial by products (18\% crude protein); ${ }^{4}$ Assumes $25 \%$ dry matter in green forage and $90 \%$ dry matter in both concentrate and straw; ${ }^{5}$ Four cows were included in this group; ${ }^{6}$ There were 16 crossbred cows and 12 buffalo in this group; 'There were 154 animals in the study. These are on small farms in five different villages with a minimum of two similar animals with each farmer. One animal received the basal diet and one animal was given access to UMNB.

two essential functions:

-promote efficient microbial growth in the rumen, and

-increase protein supply for digestion in the small intestines (bypass or rumen nondegradable proteins);

Such sources include the following inter alia:

-non-protein nitrogenous sources such as poultry litter, and crop residues e.g. cotton seed cake;

-multi-nutrient mixtures involving molasses and mineral sources made into liquid mixtures or solidified into blocks and served as licks (MNBL);

-leguminous forages that have a low level of tannins (1-3\%), dried or heat treated. Good examples are Acacia spp., Gliricidia maculata, Leucaena leucocephala and Prosopis juliflora;

Of these methods of supplementation, the use of specific supplements such as cottonseed cake and MNBL is quite widespread, followed by the use of leguminous forages which is growing in importance.

An example of the first type of supplement concerns impressive results of work done in China in the use of cottonseed cake for beef production. The following aspects highlight the success of this work (Dolberg and Finlayson, 1995):

-the project output of 3000 MT of treated straw (with $3 \%$ anhydrous ammonia or $5 \%$ urea) was exceeded by an estimated $150 \times 106$ MT or more than $4000 \%$ in the project countries; -a supplement of $1.5 \pm 0.5 \mathrm{~kg}$ of cottonseed cake gave daily growth rates of between 600 $700 \mathrm{~g}$ and a $450 \mathrm{~kg}$ slaughter weight in two year old crossbred cattle;

-profitability analyses in terms of per head or per day indicated distinct financial benefits to farmers;

-cottonseed cake supplementation in this case, significantly reduced the dependence on more expensive purchased concentrates, and -increased beef production making optimum use of local feeds is clearly a viable activity in small farms;

In recent years, MNBL are being widely used throughout many parts of Asia and Africa with increasing success and economic benefits (Sansoucy, 1995). Table II illustrates one example of the value of MNBL in recent studies at the village level in India, even where buffalo and cattle have been fed considerable amounts of a concentrate, green forage and millet straw. Supplementation with MNBL improved milk yield by an average of $30 \%$. Similar results have also been reported in many countries in South East Asia and Africa.

A third option concerning supplementation, and one which unfortunately has not been adequately applied concerns the use of a variety of leguminous forages. Their use as supplements is underestimated, since there 
exists throughout the tropics considerable germplasm diversity and availability. Despite this diversity, past research and development activities have tended to work on a very narrow range of fodder trees in which Leucaena and Gliricidia in Asia and Africa, and Erythrinia in Latin America have been prominent. There is considerable potential to include many more important tree forages like Acacia spp. and Trichantera gigantica.

Forage production from the trees and shrubs is dependent on a number of agronomic and management factors, taking into account their multi-purpose use such as in fuel wood. The most important factors affecting productivity are plant density, plant configuration, cutting management (time of first cutting and height, frequency, and season of cutting) and fertilizer use (Ivory, 1990). The types of production are:

-single hedgerows (fencelines and rice bunds); -multiple rows (uncultivated lands, contour and pasture areas);

-intensive systems high plant densities;

Forages from trees have a number of advantages. The advantages include inter alia (Devendra, 1988): availability in the farms; accessibility; provision of variety in the diet; source of dietary nitrogen $(\mathrm{N})$, energy minerals and vitamins; laxative influence on the digestive tract; reduction in the requirements for purchased concentrates; reduced cost of feeding.
With Leucaena for example, it provides a valuable source of protein, energy and sulphur for the rumen bacteria. It is also valued, like many other tree legumes, in multi-purpose use in fencelines and as a fuel.

The manner in which the forage is fed is important and includes chopping, separating leaves from the stems and also sun drying. Recent studies have clearly shown that simple drying of the foliage has an effect in its quality as supplement; table III demonstrates this point. With cassava leaves (Manihot esculenta Crantz), the effect of sun drying is to reduce the content of hydrocyanic acid which is fatal to the animal if the leaves are fed fresh.

Table IV highlights the responses in goats fed with a variety of leguminous forages. In all cases, there was beneficial responses which were economic. Likewise, the use of these leguminous forages across species and the significance of shrubs and tree fodders as sustainable feed resources has recently been reviewed (Devendra, 1993a). Farmers often feed mixtures of tree leaves to provide variety in the diet, extend the feed preferences of ruminants, as well as meat the nutrients needs for body function.

\section{Food-feed system}

Associated with the use of forage legumes as supplements, is the integration of these fodder

Table III. Comparison of the effect of tree foliage supplements fed fresh or after drying to goats fed a basal diet of rice straw (Norton, 1994).

Forage intake (g/kg LW/day) Tree foliage

\section{Supplement}

Albizia chinensis

Calliandra calothysus

Glyricidia sepium

Leucaena leucocepha

Sesbania sesban

$$
\text { Fresh }
$$

\section{5}

7.5

\section{5}

\section{5}

7.5
Basal Dry matter digestibility (\%) Growth rate (g/day)

18.5

16.5

18.5

18.5

18.5

15.5

15.5

18.5

14.5

17.5

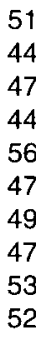

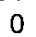

54

24

48

12

42

$-18$

0

0

54 
Table IV. Results of the benefits of forage supplements for goats.

\begin{tabular}{lcccll}
\hline Breed & Major feed & $\begin{array}{c}\text { Type of forage } \\
\text { supplement a }\end{array}$ & $\begin{array}{c}\text { Significant } \\
\text { response b }\end{array}$ & Location & Reference \\
Native & Maize stover & LL & LWG & Philippines & Linggodjiwo (1976) \\
Crossbreds & Napier grass & LL & LWG & Malaysia & Devendra (1982) \\
Native & Paragass & LL & LWG & Philippines & Abayan and Boloran (1984) \\
Native & Browse & PC & LWG & India & Parthasarathy et al (1983) \\
Native & Concentrate & LL & LWG & Philippines & Abilay and Arinto (1981) \\
Kachong & P. purpureum & GS & LWG & Indonesia & Rangkuti et al (1985) \\
Native & Concentrate & PC & LWG & India & Parthasarathy (1986) \\
\hline
\end{tabular}

$\mathrm{aLL}=$ Leucaena leucocephala, $\mathrm{PC}=$ Prosopis cineraria, $\mathrm{GS}=$ Gilicidia sepium; ㄴWG $=$ live weight gain.

Table V. Comparative productivity of three strata and non-three strata forage systems $(\mathrm{kg}$ dry weight/plot/yr) (Nitis et al, 1990).

\begin{tabular}{lcc}
\hline Parameter & TSFS & NTSFS \\
\hline Food & 853 & 1266 \\
Straw & 750 & 1216 \\
First stratum & 455 & - \\
Second stratum & 310 & - \\
Third stratum & 15 & - \\
Shrubs & - & 132 \\
Trees & - & 2 \\
Improved grasses & - & 10 \\
Native grasses & - & 242 \\
Firewood & 1049 & 475 \\
Cattle live weight gain (kg/3 yr) & 186 & 166 \\
Carrying capacity (cattle/ha) & 4 & 2 \\
Maximum live weight (kg/head) & 300 & 200 \\
Soil erosion (mm/2 yr) & 11 & 20 \\
\hline
\end{tabular}

"Three strata forage system; "Non-three strata forage system.

trees in food-feed systems, and the development of sustainable production systems. Two examples from South East Asia serve to highlight this point.

\section{Three-strata forage system (Indonesia)}

The three-strata forage systems (TSFS) involving grasses, shrubs and trees is a way of producing and conserving the feed requirement of cattle and goats, without any degradation of the environment. For dryland farming areas such as in eastern Indonesia, South Asia and
North Africa, the system combines production of food crops (maize, groundnut, cassava and pigeon pea) with shrubs and trees to produce food for all year round feeding with outstanding results (Nitis et al, 1990). Major highlights of the system are summarized in table $\mathrm{V}$ as follows:

-increased forage production due to the use of Stylosanthes, Centrosema, Acacia, Gliridicia and Leucaena enabled higher stocking rates and live weight gains ( 3.2 animal unit equivalent to $375 \mathrm{~kg} / \mathrm{ha} / \mathrm{yr}$ in the TSFS compared to 2.1 animal units or $122 \mathrm{~kg} / \mathrm{ha} / \mathrm{yr}$ in 
Table VI. Rice and mungbean yields as affected by intercropping with mungbean and siratro, Pangasinan, Philippines.

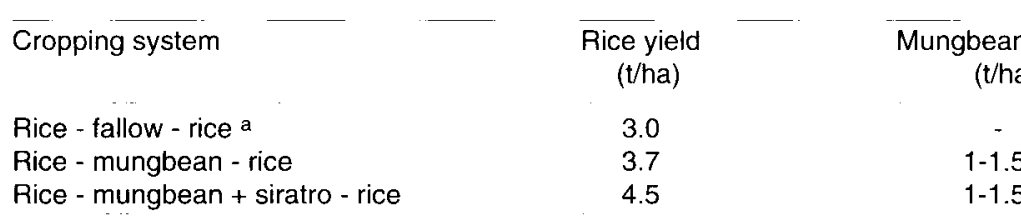

aPSB RC2 variety

the non-TSFS.

-cattle in the TSFS gained $19 \%$ more live weight and reached market weight $13 \%$ faster; -farmers in the TSFS benefited by a $31 \%$ increase in farm income;

-the introduction of forage legumes into the TSFS reduced soil erosion by $57 \%$ in the TSFS compared to the non-TSFS, together with increased soil fertility;

-the presence of 2000 shrubs and 112 trees logged twice a year produced $1.5 \mathrm{MT} / \mathrm{yr}$ of firewood, which met $64 \%$ of the farmers annual fuel requirements;

-the integration of goats in addition to cattle into the system, further increased the income of farmers;

-institutionalization of the concept and technology.

\section{Crop-animal system (Philippines)}

In the rainfed lowland areas of Pangasinan in the Philippines, rice-mungbean has replaced rice-fallow. Intercropping with siratro, and incorporation of the herbage from the last cutting two weeks before replanting into the soil as green manure resulted in higher yields of the succeeding crop (table $\mathrm{VI}$ ).

In addition, cattle fed with rice straw as the basal feed and strategic supplementation with forage legumes (siratro and mungbean), rice bran and urea was generally beneficial to stimulate live weight gain and reduce live weight loss. Farmers in this area have now widely adopted the use of strategic supplementation and the use of the available feeds from the rice-mungbean + siratro - rice cropping systems for cattle for draught and meat. The benefits of this system are: -increased yield of rice and farm income; $-50-70 \%$ reduced dependence, and cost of organic fertilizers;

-increased forage biomass;

-increased carrying capacity of cattle $(1 \rightarrow 6$ cows);

-the ability of siratro to resist drought provides valuable food for cattle calving at the end of the wet season (November) and on set of the dry season (October) when feed deficits are a major constraint to production;

-development of all year round feeding systems:

-increased output from animals.

\section{Intensifying the use of fodder resources}

Considerable opportunities exist for intensifying and extending the use of the fodder resources. The objective is especially true for FCR where the utilization of research results merits high priority. With rice straw for example, the importance of extending known technologies through on-farm testing and demonstration far outweighs the need for further demonstration of the effects of pre-treatments and or supplementation (Doyle et al, 1986; Devendra, 1991). Thus, experiments on large scale onfarm tests are relatively fewer compared to a plethora of work done, often duplicated, at the laboratory and experiment station level.

A concerted programme of on-farm animal research and development is necessary to extend the adoption of technology packages that are economically and socially acceptable to farmers, taking into account all aspects of the prevailing farming systems and the ecosystem. Such technologies must be targeted at overcoming real constraints at the farm level, and concurrently serve as a means to significantly increase productivity from 
animals. The work on large scale straw utilization for beef production in China is a unique example of what needs to be done (Dolberg and Finlayson, 1995).

The approach to address concerted onfarm animal research involves two phases as follows:

\section{Phase I: Information needed by farmers and their advisers.}

1-Choice of feeds and their availability over seasons.

2-Detailed information on composition of feeds, nutritional value, prediction of changes during periods of production, capacity to meet production targets and capability of filling any nutritional gap.

3-Effects of strategic supplementation on animal performance, economic response, sustained production of the basal feed resources and methodology of use.

4-Appropriate feeding systems.

5-Level and type of production (meat, milk and/or draught).

6-Realistic production targets.

\section{Phase II: Mechanisms for the delivery of information to farmers}

7-Methodology: balance between fundamental and applied research.

8-Linkages across disciplines and institutions.

9-Demonstration of economic benefit.

10-Large scale on-farm testing.

11-In situ utilization.

12-Farmer participation, and

13-Definition of a model for feeding resource development.

There is no doubt that a concerted programme, based on interdisciplinarity and a strong systems approach, aimed at large scale utilization of the fodder resources throughout the year can go a long way to increase productivity from animals. With this, a shift from the more extensive to intensive production systems is inevitable, but these must address the totality of production-post-productionconsumption systems (Devendra, 1993b). Such a strategy will provide for more effective use of the fodder resources in sustainable animal production systems.

\section{Literature cited}

Abayan PE, Boloran LB (1984) The effects of feeding fresh ipil-ipil leaves (Leucaena leucocephala [Lam] de Wit) and para grass (Brachiaria mutica Forsk Staph) combined with concentrate on the growth rate of yearling goat. Central Mindanao University, Philippines. J Agric Fd Nutr 5, 739754

Abilay TA, Arinto (1981) The influence of ipil-ipil (Leucaena leucocephala [Lam] de Wit), leaves feeding on the reproductive performance of goats in the tropics. In: Proc Int Symp Nutr Syst goat feeding, 2, INRA, Tours, France, 623-634

Balch CC, Campling RC (1962) Regulation of voluntary food intake in ruminants. Nutr Abstr Rev 32, 669-686

Chenost M (1966) Fibrousness of forages: its detrermination and its relation to feeding value. In: Proc Xth Internat Grassid Congr, Helsinki, section 2, 406-411

Chesson A, Stewart CS, Dalgarno K, King TP (1986) Degradation of isolated grass mesophyll, epidermis and fiber cell walls in the rumen and by cellulolytic rumen bacteria in axenic culture. $\checkmark$ Appl Bacteriol 60, 327-336

Devendra C (1982) The nutritive value of Leucaena leucocephala cv Peru in balance and growth studies with goats. MARDI, Res Bull 10, 1338150

Devendra C (1988) Forage suppplements: nutritional significance and utilization for draught, meat and milk production. In: Proc 2nd World Buffalo Congr, ICAR, New Delhi, India, 409-423

Devendra C (1991) Technologies currently used for the improvement of straw utilization in ruminant feeding systems in Asia. In: Proc NRI/MARDI Workshop on the utilization of straw in ruminant production systems (DL Romsey, ER Ørskov, M Gill, eds) 1-19

Devendra C (1993a) Trees and shrubs as sustainable feed resources. Proc VII Wrid Conf Anim Prod 1, 119-138

Devendra C (1993b) Sustainable animal production from small farm systems in South East Asia. FAO Anim Prod Hith Paper 106, 143p

Devendra C (1995) Composition and nutritive value of browse legumes. In: Tropical legumes in animal nutrition, CAB Intern (JPF D'Mello, C Devendra, eds) Wallingford, Oxon, England, 49-66

Devendra C, Burns N (1983) Goat production in the tropics. CAB, Farnham Royal, UK, 183p

Dolberg F. Finlayson P (1995) Treated straw for beef production in China. World Anim Rev (FAO) 82 , 14-24 
Doyle PT, Devendra C, Pearce GR (1986) Rice straw as a feed for ruminants. Intern Devel Program of Austr Univ Colleges, Canberra, Australia, 117p

International Livestock Research Institute (1995) Global agenda for livestock research - Proc Consultation (P Gardiner, C Devendra, eds) Nairobi, Kenya, 114p

Ivory D (1990) Major characteristics, agronomic features, and nutritional value of shrubs and tree fodder. In: Shrubs and tree fodders for farm animals, IDRC 276e (C Devendra, ed) Ottawa, Canada, 22-38

Le Houerou HN (1978) The role of shrubs and trees in the management of natural grazing lands. In: 8 th World Forestry Congr, Jakarta, Indonesia (Mimeograph)

Le Houerou HN (1980) (ed) Browse in Africa - Proc Int Symp Intern Livestock Centre for Africa. Addis Ababa, Ethiopia, 491p

Leng RA (1982) Modification of rumen farmentation In: Nutrition limits to animal production from pastures, $C A B$ (JB Hacker, ed) Farnham Royal, England, 427-453

Leng RA (1986) Determining the nutritive value of forage. In: Forages on Southeast Asian and South Pacific Agriculture (GJ Blair, DA lvory, TR Evans, eds) ACIAR Proc, Canberra, Australia, $12,111-123$

Leng RA, Devendra C (1995) Priorities and direction for more effective use of feed resources research in Asia. In: International Livestock Research Institute, Consultation on Livestock Research Priorities in SouthEast Asia (C Devendra, P Gardiner, eds) Nairobi, Kenya, (In press).

Linggodjiwo (1976) Feedlot fattening of cattle and goats with ipil-ipil (Leucaena leucocephala) leaves and molasses urea. Thesis. University of the Philippines, Los Banos, Philippines.

Lowry BJ, Petheram JR, Tangendjaja B (1992) Plants fed to village ruminants in Indonesia. ACIAR Tech Rep Canberra, 22, 60p

Minson DJ (1988) Chemical composition and nutritive value of tropical legumes. In: Tropical forage legumes. (PJ Skerman, PJ Cameron, F Riveros, eds) FAO, Rome, Italy, 185-193

Minson DJ (1990a) The chemical composition and nutritive value of tropical forages. In: Tropical Grasses (PJ Skerman, F Riveros, eds) FAO, Rome, Italy, 163-180

Minson DJ (1990b) Forages in ruminant nutrition. Academic Press, London, England, 483p

Nitis IM, Lana K, Sukhanten W, Suarna M, Putra S
(1990) The concept and development of the three strata forage system. In: Shrubs and tree fodders for farm animals (C Devendra, ed) IDRC276e, Ottawa, Canada, 92-102

Norton BW (1994) Tree legumes as dietary supplements for ruminants. In: Forage tree legumes in tropical agriculture (RC Gutteridge, HM Shelton, eds) CAB International, Wallingford, Oxon, England, 177-191

Parthasarathy M (1986) Effect of feeding levels of Khejri (Prosopis cineraria) leaves and concentrate on the performance of weaner kids. Indian J Anim Nutr 3, 249-253

Parthasarathy M, Singh D, Rawat PS (1983) Effect of supplementation on the performance of weaner kids. Indian J Anim Sci 53, 671-672

Poppi DP, McLennan SR (1995) Protein and energy utilization by ruminants at pasture. J Anim Sci 73 . 278-290

Poppi DP, Gill M, France J, Dynes RA (1990) Additivity in intake models. In: Modelling Digestion and Metabolism in Farm Animals (AB Robson, DP Poppi, eds)Proc Third Int Workshop, Lincoln University, New Zealand, 29-46

Sansoucy R (1995) Recent developments on the use of molasses urea block licks. World Anim Rev (FAO) 82, 78-83

Sarson M, Salmon P (1978) Rôles des arbres et des arbustes fourragers dans l'aménagement des pâturages naturels en Afrique du Nord. In: 8th World Forestry Congr Jakarta, Indonesia, Mimeograph, $14 p$

Sumberg JE (1984) Small ruminant feed production in a farming systems context. In: Proc workshop on small ruminant prod systems in the humid zone of West Africa, Ibadan, Nigeria, 41-46

Troelsen JE, Campbell JB (1969) The effect of maturity and leafiness on the intake and digestibility of alfalfa and grasses fed to sheep. $J$ Agric Sci 73, 145-154

Vecht J, Landau S, Perevolotsky A, Zeltser S, Eliasoff $L$, Zoref $Z$ (1991) The effect of reducing the concentrate allowance of dairy goats grazing mediterranean pastures on milk production and composition and its economic implications. In: Proc 4th int Symp on machine milking of small ruminants (M Itam, ed) Kihbutz Shejayin, Israel, 680-690

Wilson JR, Dienum B, Engels FM (1991) Temperature effects on anatomy and digestibility of leaf and stem of tropical and temperate forage species. $J$ Agric Sci Netherlands, 39, 31-48 